\title{
Exploring on the Cultivating Model of the Combination of Working and Learning in Higher Vocational Education
}

\author{
Liu Liying* (Corresponding Author) \\ College of Public Management \\ Tianjin Vocational Institute \\ Tianjin, China \\ liuliying0718@163.com
}

\author{
Wang Shuwen \\ College of Public Management \\ Tianjin Vocational Institute \\ Tianjin, China \\ 739796426@qq.com
}

\author{
Yang Renjie \\ College of Engineering and Technology \\ Tianjin Agricultural University \\ Tianjin, China \\ rjyang1978@163.com
}

\author{
Zhao Yue \\ College of Public Management \\ Tianjin Vocational Institute \\ Tianjin, China \\ 49004988@qq.com
}

\begin{abstract}
Higher vocational college students should have professional and practical talents. The skilled personnel should have a strong ability of professional development, and can quickly adapt to the needs of enterprises and society. However, the current higher vocational education graduates cannot fully meet the needs of enterprises; the main reason is that the higher vocational education and the actual production of enterprises are out of touch. It is an effective way to solve the problem in the construction of national demonstrative higher vocational colleges, which is based on the combination of working and learning. In the implementation process, students to allow to personally undergo the complete work process. Vocational colleges should actively update their concepts, create conditions, solid work, and promote the integration of working and learning mechanism innovation. At the same time, the bridge relations of students, enterprises, and institutions are constructed to achieve a win-win situation for the three parties, so as to promote the development of higher vocational education.
\end{abstract}

Keywords-Higher Vocational College, The Combination of Working and Learning, The Cooperation of College and Enterprise, System Innovation

\section{INTRODUCTION}

In recent years, with the continuous expansion of the scale of higher vocational education in our country, the number of colleges and universities in is about 9.5 million students in 2016 year, indicating that China has entered the ranks of higher vocational colleges. It shows that higher vocational education is more and more important in national education. The ministry of education pointed out that it is necessary to actively carry out the study mode of combining production labor and social practice. The combination of working and learning is an important part of the reform of the personnel training mode of higher vocational education, which promotes the professional adjustment and construction and guide the reform of curriculum, teaching content and teaching methods. The combination of working and learning is that education should be closely integrated with the needs of enterprises and society. In the course of teaching practice, the field experts with rich practical experience are invited to participate in the process of personnel training, so as to realize the cooperation between schools and enterprises, and with the help of the equipment, resources and environment. Furthermore, students can learn the purpose of working on the enterprise platform. Compared with foreign countries, the implementation conditions of the training mode of the combination of working and learning are relatively short in our country. Therefore, it is necessary to set up the theme, function and structure of the model in accordance with the national conditions. All the higher vocational colleges in the country are actively exploring and innovating the training mode of the combination of working and learning with Chinese characteristics[1].

The talent cultivation mode of higher vocational education bears the idea of higher vocational education, which embodies the goal of talent cultivation of higher vocational education, and reflects the requirements of the development of social economy and the vocational education. As the innovation of the training mode of higher vocational education, the combination of working and learning plays an important role in deepening the teaching reform, refining the specialty characteristics and creating the characteristic brand. In recent years, a lot of useful exploration on the training mode of higher vocational education has been done in our country, and accumulated some experience. However, the cultivation mode of talents in many vocational colleges is far from the requirements of talent training. It is difficult to highlight the characteristics of higher vocational education. It is a hot topic to study the reform and innovation of talent cultivation mode in higher vocational colleges. Choosing the talent training mode of international higher vocational education or explore

\footnotetext{
1. Tianjin Educational Science and Planning Project (VE3147).

2. Education Reform and Innovation Development Funds of Tianjin Agricultural University (20170202)
} 
the talent training mode with Chinese characteristics, going boldly in practice on the road or stopping the pace of time for theoretical reflection are about the confusion faced by every higher vocational education. It is important problem for higher vocational colleges and educators to do a good job of the combination of working and learning.

\section{Clarifying THE StATUS OF THE COMBINATION OF WORK AND STUDY}

At present, the majority of teachers are lack of practice in higher vocational colleges. Due to the influence of the traditional higher education, the curriculum system and teaching contents emphasize the systematicness of the theory. The school and classroom as the center of talent training mode is not conducive to the cultivation of practice ability and the occupation quality, will seriously affect the quality and characteristics of talent cultivation in higher vocational colleges, which affects the survival and development of higher vocational education

The combination of working and learning is a kind of education form for higher vocational students in higher vocational colleges [2]. It is a great innovation and profound reform of the talent-training mode of higher vocational education. The most important feature of the combination of working and learning is the openness, practicality and professionalism in higher vocational colleges. To implement the combination of working and learning for higher vocational students, it means to go out of the classroom of pure theory teaching, takes the "professional person" as an identity to participate in the practical work, and learn and grow in the work practice. Fig.1 represents the relationship between the enterprises, students and colleges in the model of the cooperation between school and enterprise. On one hand, there are teachers in charge of supervision and guidance of the enterprise; On the other hand, the college teachers help the organization and management of the students. For higher vocational students, the combination of working and learning can make the learning career and career to be connected as soon as possible to realize the transformation of the role of the students to the professional role. For the enterprise, the combination of working and learning can help people with their education through to the students' education training, so as to be able to receive their required practical talents, to provide high quality human resources for the development of enterprises [3]. At the same time, it can also use the college professor to train the employees of the enterprise to improve the cultural quality of the employees. For higher vocational colleges, the combination of working and learning can make full use of production conditions and professional atmosphere to strengthen the cultivation of students' occupation occupation skill and occupation moral education, extend the classroom to the production site, production to achieve the purpose of educating people. Meanwhile, The employment and education are closely linked, which fully embodies the main principle of "the aim of service, the lead of obtaining employment".

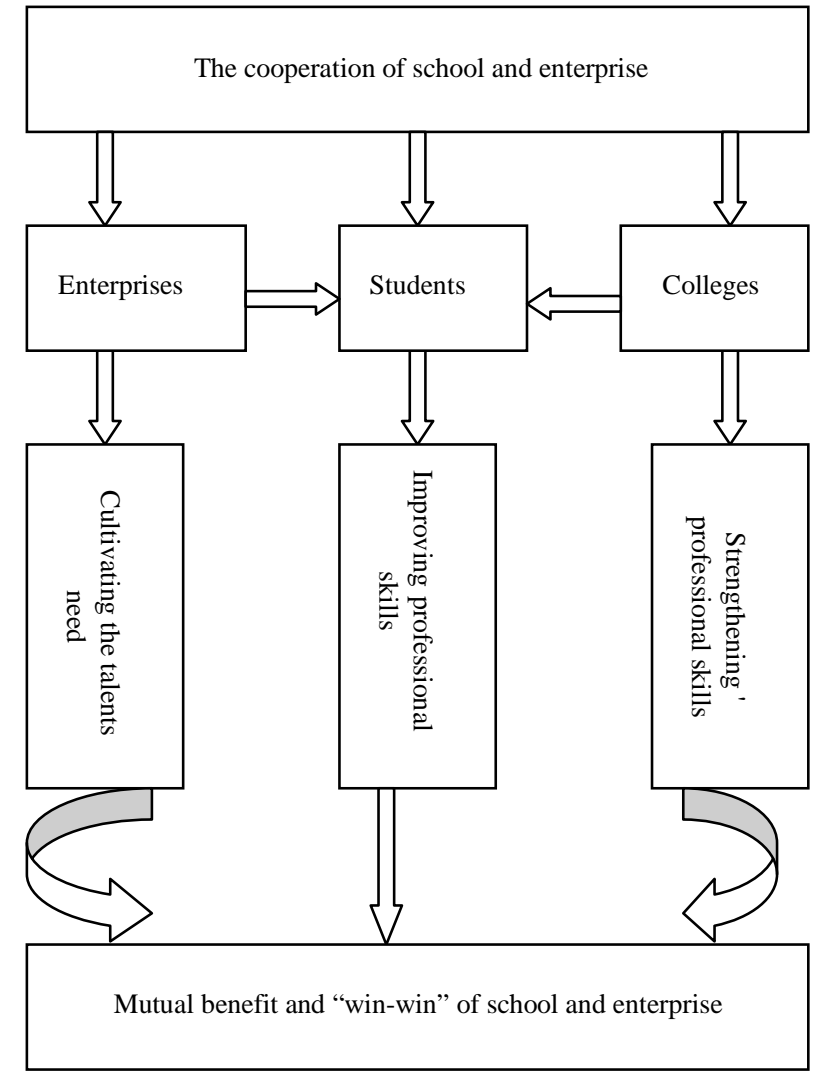

Fig. 1. The relationship between the enterprises, students and colleges in the model of school and enterprise cooperation

\section{ESTABlishing THE EFFECTIVE MANAGEMENT SySTEM OF THE COOPERATION OF SCHOOL AND ENTERPRISES}

In order to implementation of the training model of combination of working and learning, school should construct perfect management system to enable students to participate in the production process. At present, the enthusiasm of enterprises to participate is not high in school enterprise cooperation; the main reason lies in the enterprise itself, schools and government policies. Due to the different tasks of the school and the enterprise, it is difficult to realize the problems in the process of their interests and cooperation. In order to better serve the local economy and give full play to the advantages of the school, the needs of enterprises should be paid close attention. School and enterprises should carry out a comprehensive, in-depth, multi form of cooperation, the formation of complementary resources of school and enterprise. A "win-win" development model can be achieved by mutual support and common development of school and enterprise. The problems in the process of the implementation of the cooperation of school and enterprise should be restricted by the standard system, and a set of effective management system should be established (Fig.2). 


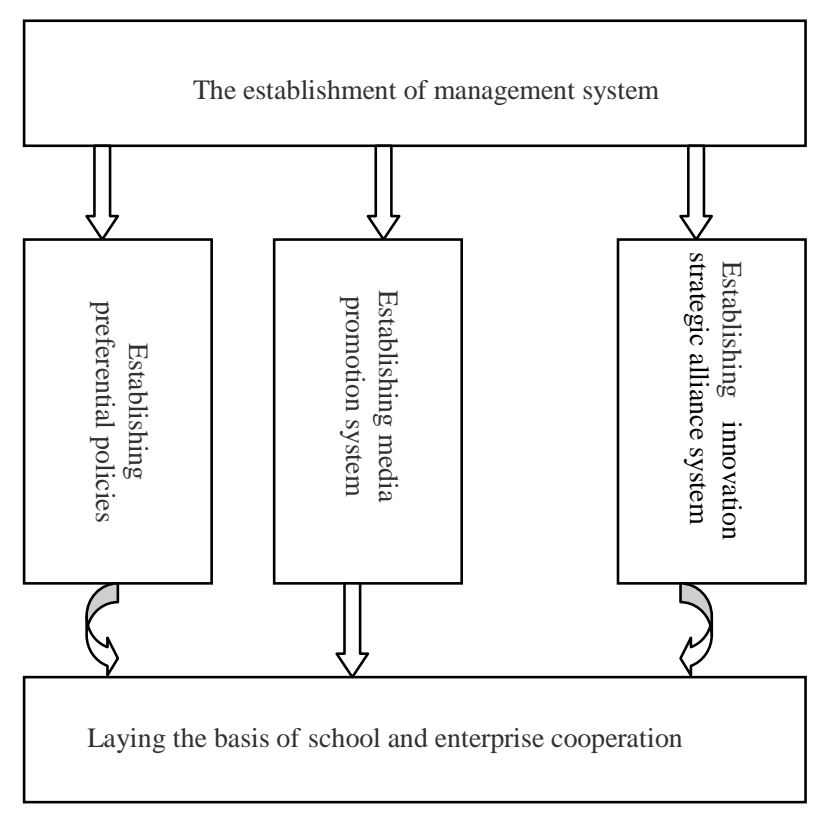

Fig. 2. The establishment of management system of the cooperation of school and enterprise

\section{A. Establishing the Preferential Policies}

The success of the cooperation between school and enterprise is based on mutual benefit. The purpose of cooperation is "mutual benefit and win-win", which should enjoy equal rights and obligations. Due to the active position of the enterprise in the employment, schools and enterprises have not yet established a solid win-win mechanism of school enterprise cooperation. The main reason is that the enterprise is based on its own economic benefits. Therefore, the cooperation between school and enterprise to protect the rights of enterprises, such as participating in the cooperation with enterprises to enjoy preferential tax subsidies, personnel, technology priority right, and enjoying preferential policies in the development of products and payment etc. It has the right to ensure the normal production order of higher vocational colleges, has the right to require students to try to save costs and create profits, has the right to speak in the training objectives, professional construction, curriculum, teaching forms, training practice and the construction of teaching staff, and other aspects [4].

\section{B. Establishing Effective Media Promotion System}

The cooperation between school and enterprise in higher vocational colleges is under the tide of market economy, which can be a public affair that attracts public attention. Social media can get consumers and social public recognition through the promotion of enterprise culture, product features, business philosophy to promote enterprise brand, which lays the foundation of public psychology for the enterprise brand and products into the market, expand the market. Social media should play the role of rapid dissemination of information, leading the market, and promote the development of the cooperation between school and enterprise. This should be the social responsibility of the media. Social media should build a platform for more enterprises and schools to, so that enterprises can improve the reputation and influence of enterprise and product by using the window of the school. The media should form regular propaganda or open up special channels or pages to report the cooperation of school and enterprise, cooperation and cooperation. So that enterprises can fully understand that only actively participate in school enterprise cooperation, in order to better disseminate corporate information, display corporate image, shaping the corporate brand. Furthermore, the visibility, reputation and brand effect of the enterprise can be improved in the public awareness, make the enterprise initiative willingness to cooperate.

\section{Establishing Innovation Strategic Alliance System}

From the present point of view, higher vocational colleges can work closely with enterprises and other social forces and develop together. The key lies in the level of scientific research in higher vocational colleges. For higher vocational colleges, if there is no high level of scientific research team, no strong technical service ability of the team, there is no market development potential of scientific research results, it is impossible to achieve "win-win" cooperation between school and enterprise. If the higher vocational colleges have no status and no advantage in the cooperation, the enterprises cannot participate in the school enterprise cooperation sincerely and continuously.

Higher vocational colleges should renew the idea of cooperation between colleges and enterprises, and improve their teaching quality, scientific research and social service. At the same time, higher vocational colleges should set up scientific research and research direction according to the development needs of enterprises, and form the strength and charm to attract enterprises to participate in the cooperation, and provide active, comprehensive, multi-level services for enterprises. Higher vocational colleges should construct the enterprise technology innovation strategic alliance, which takes the enterprise as the main body, the market as the guidance, the school and the enterprise to participate together, and the combination of production, learning and research [5]. Through the innovation strategic alliance system, school and enterprises can commonly develop, with complementary advantages, benefit sharing, and risk sharing. At the same time, through innovation strategic alliance system of the cooperation between school and enterprise, the enterprise's technological innovation ability can be enhanced, promoting the economic structure adjustment and industrial optimization and upgrading, and enhancing the core competitiveness of enterprises. Higher vocational colleges and enterprises can achieve their own interests through innovation strategic alliance system of the cooperation between school and enterprise. Further, the cooperation between school and enterprise become a conscious behavior, the real establishment of the cooperation between school and enterprise, to seek a win-win and longterm mechanism.

\section{PROMOting The INSTITUtional INNOVATION OF Higher VOCATIONAL COLLEGES}

First of all, the organization and management of the cooperation between colleges and enterprises are established. 
College should set up an office of school enterprise cooperation education for external getting in touch with cooperation unit, communication information, signing an agreement, handling related matters; for internal contacting with the relevant departments and the department of teaching for implementing of cooperation projects, solving the difficulties and problems in the process of cooperation. The organization and management of the cooperation between colleges and enterprises can make integration of working and learning education and external social services and school enrollment, employment, teaching, research, training, skills identification and other aspects. It can improve the response ability and service ability of colleges and universities to the change of market demand, improves the quality of personnel training, and promotes the high quality and stable employment of graduates. The professional construction steering committee should be established by the school department of teaching, which is composed of heads of department and relevant enterprises technical experts, management experts, human resources experts [6]. Its main responsibility is to be responsible for the professional setting, professional training objectives, professional teaching plans and professional development planning of the demonstration and validation, the specific guidance of professional teaching reform and professional development.

Secondly, the relationship between the combinations of working and learning should be strengthened to improve the practical effect for students. Colleges should solve the problem of finding cooperative enterprises, reaching cooperation intentions, signing cooperation agreements, organizing teachers and students to enterprises, and employing technical personnel with practical experience. Colleges and enterprises need coordinate with each other to solve the arrangement of teachers and students to participate in the practice of teaching reform in colleges and universities of education, to coordinate the relationship between the training personnel and production management and so on. Obviously, it is much more difficult compared with the traditional teaching mode of personnel training. Therefore, it is necessary to straighten out the relationship between colleges and enterprises to establish an organic unity of the combinations working and learning interests of the community, so that the interests of the parties concerned, aspirations, requirements can be timely and effective expression and communication. It can lay the foundation for the combinations of working and learning through communication and coordination. Only in this way, the enthusiasm of enterprises, colleges and students can be fully mobilized to participate and comprehensively promote the combinations of working and learning.

\section{CONCLUSIONS}

From the result, the cultivating model of the combination of work-study was constructed based on the close cooperation between school and enterprise. Through the social media propaganda and innovation strategic alliance system, the higher vocational colleges play the main role for providing the high quality talented person for the enterprise. By actively participating in the combination of working and learning, enterprises can obtain the professional and technical personnel, which can meet the needs of enterprises, and enhance their competitiveness and creativity. Through the combination of work-study, students not only can learn knowledge in school, but also can obtain professional skills in enterprise through training, and become a real versatile and practical operation. It can lay a solid foundation for the improvement of their own quality increasing opportunities. Win-win cooperation between colleges and enterprise can be obtained under the model of model of the combination of work-study.

\section{ACKNOWLEDGMENT}

This work was financially supported by Tianjin 13th FiveYears Educational Science and Planning Project (VE3147) and the Education Reform and Innovation Development Funds of Tianjin Agricultural University (20170202).

\section{REFERENCES}

[1] Liu Liying. Study on the cultivation system of vocational development ability of higher vocational college Students under the mode of the combination of work-study[J]. China Adult Education. 2015, 14: 105106. (In Chinese)

[2] Zhang Liang. Problems existed in teaching management of higher vocational education under the model of working and learning combiantion and the countermeasutes [J]. Vocational and Technical Education, 2010, 31(11): 74-76. (In Chinese)

[3] Tan yongping. Improvement for course system of exploration technology and engineering based on specialized direction of alumni [J]. Higer Education Forum, 2016, 7: 79-82. (In Chinese)

[4] Jiang Fang, Xiao Qi. Problems and countermeasures of teaching management in higher vocational colleges under the mode of work study combination[J]. Education and Vocation, 2015, 28: 25-27.(In Chinese)

[5] Zhao Baofang, Han Zhensheng, Wang Yan. Research on problems of practice teaching conditions under work-study combination talents training pattern in vocational colleges[J]. Higher Vocational EducationJournal of Tianjin Vocational Institute, 2010, 19(1): 30-32+48.(In Chinese)

[6] Liu Jixiu, Wang Xiumei. Study on the construction of teaching materials under the mode of combining work with study in higher vocational colleges[J]. Journal of Tianjin Academy of Education Science, 2009, (3): 67-68. (In Chinese) 